\title{
ENGLISH FISHERY RESEARCH IN NORTHERN WATERS
}

\author{
Michael Graham*
}

T.

ThE research trawler Ernest Holt-named after a pioneer fishery naturalistwas built for the Ministry of Agriculture and Fisheries to carry out hydrographical and biological research in the area of the English arctic fishery at all seasons of the year (Fig. 1). In 1949 it was believed that work in the Barents Sea would be possible through the winter, given a sufficiently good sea-ship, which she has proved to be, and one that is generously heated and lighted. The effects on the operators of darkness, cold, and bad weather, have not usually proved serious, and no explorers' hardships have had to be endured; nor any heroic feats performed. Nevertheless, it may be noted that the margin of practicability has not been large. It has been necessary to reduce all operations to the simplest possible form, foregoing anything too clever, either in apparatus or in aims. For example, at the beginning the number of thermometers lost or broken was lamentably high, higher than could be readily explained to those who had not participated in the work. The circumstances of every loss or breakage have been reviewed, and have always been found to be due to some mistake in handling that the staff would not normally be expected to make. Apparatus and procedure have therefore been simplified, although it has proved impossible to dispense with the highly accurate mercury-in-glass thermometers. However, after the simplification, losses have not been serious.

The Master of the Ernest Holt, formerly Captain W. R. Ingham, now Captain H. J. Aldiss, has found it just possible to navigate in the regions where either the sky or the horizon is nearly always obscured by fog, cloud, or snow-storm, even in summer. It has been found necessary to engage a Navigator, Mr. E. A. Binnington, in order to keep track of all the ancillary information from radar, $W / T$, and soundings, such as they are on charts on which even the position of the land is not always free from doubt.

The ship herself looks like a commercial arctic trawler, except that she is painted like the other research vessels of the Ministry: black hull, white upperwork, and buff funnel crowned black. On the fly of her Blue Ensign is the dolphin and crown of the Fisheries Department's ships. The over-all length is 193 feet; length (b.p.) 175 feet; breadth 30 feet, and depth 16.0 feet. Her oil-fired triple expansion engines develop 900 I.H.P. giving her a cruising speed of 11 knots.

Her workmanlike trawler appearance results from a deliberate decision to preserve a trawler's ample deck-space, and the stability that comes from absence of top-hamper. This necessitated putting the main laboratory below

*Director, Fisheries Laboratory, Lowestoft, England. 


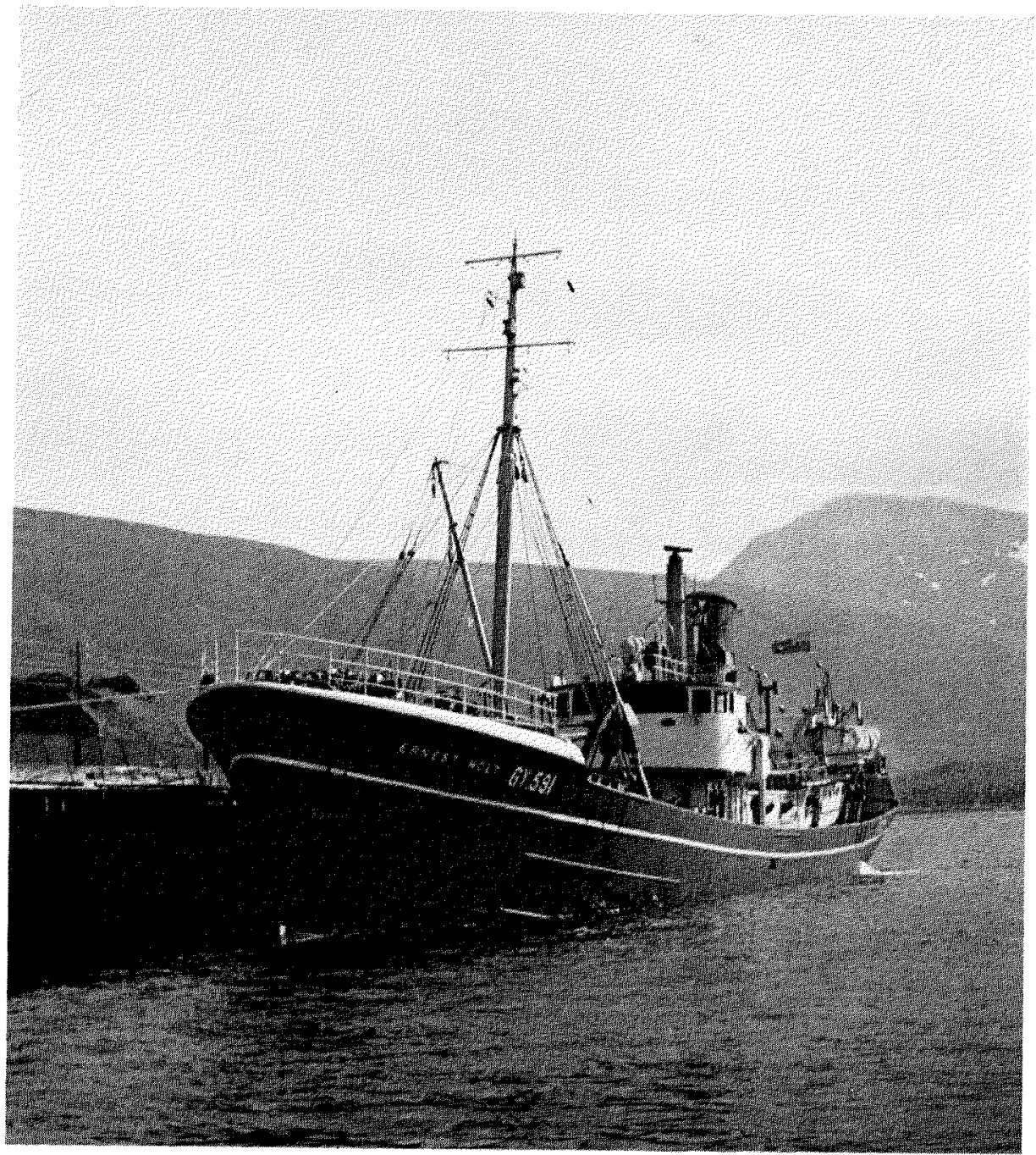

Fig. 1. The Ennest Holt in Tromso, her refuelling port.

Photo: W. J, Muguins

decks, a decision that has not been regretted. The main laboratory and living accommodation occupy the space usually allotted to the fish-room, which in the Ernest Holt is small. She does from time to time land and sell a few hundred pounds' worth of fish. Space has been found, however, for small working laboratories on deck, one hydrographical and one biological, where material is first examined and reduced to the smaller bulk that can be transferred down to the main laboratory in a small elevator.

Skipper John Monger has trained his crew to work the trawl as well as any other fishermen in the area, so that information on this ship's catch means something definite to other fishermen; but here too, the requirements of research have demanded just that much more, which has only just been 


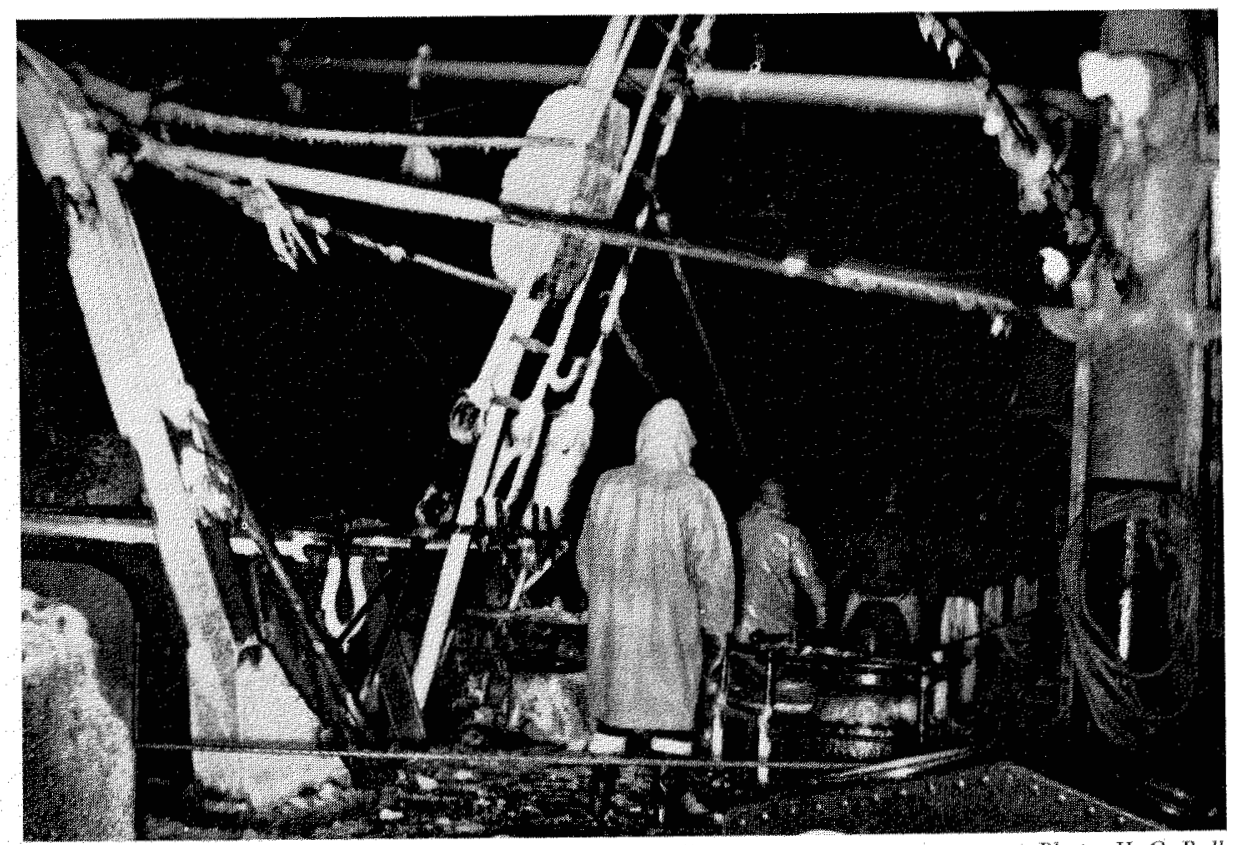

Fig. 2. I rawling in poor weather in the Subarctic.

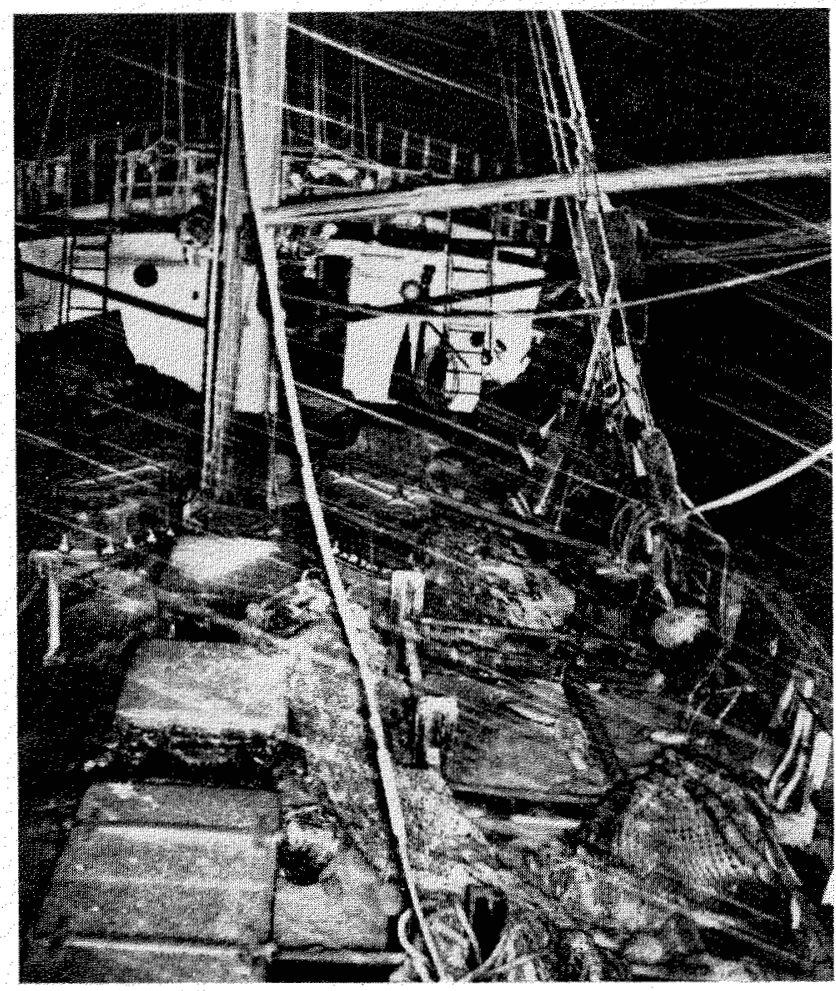

Fig. 3. Trawling stopped by storm. 


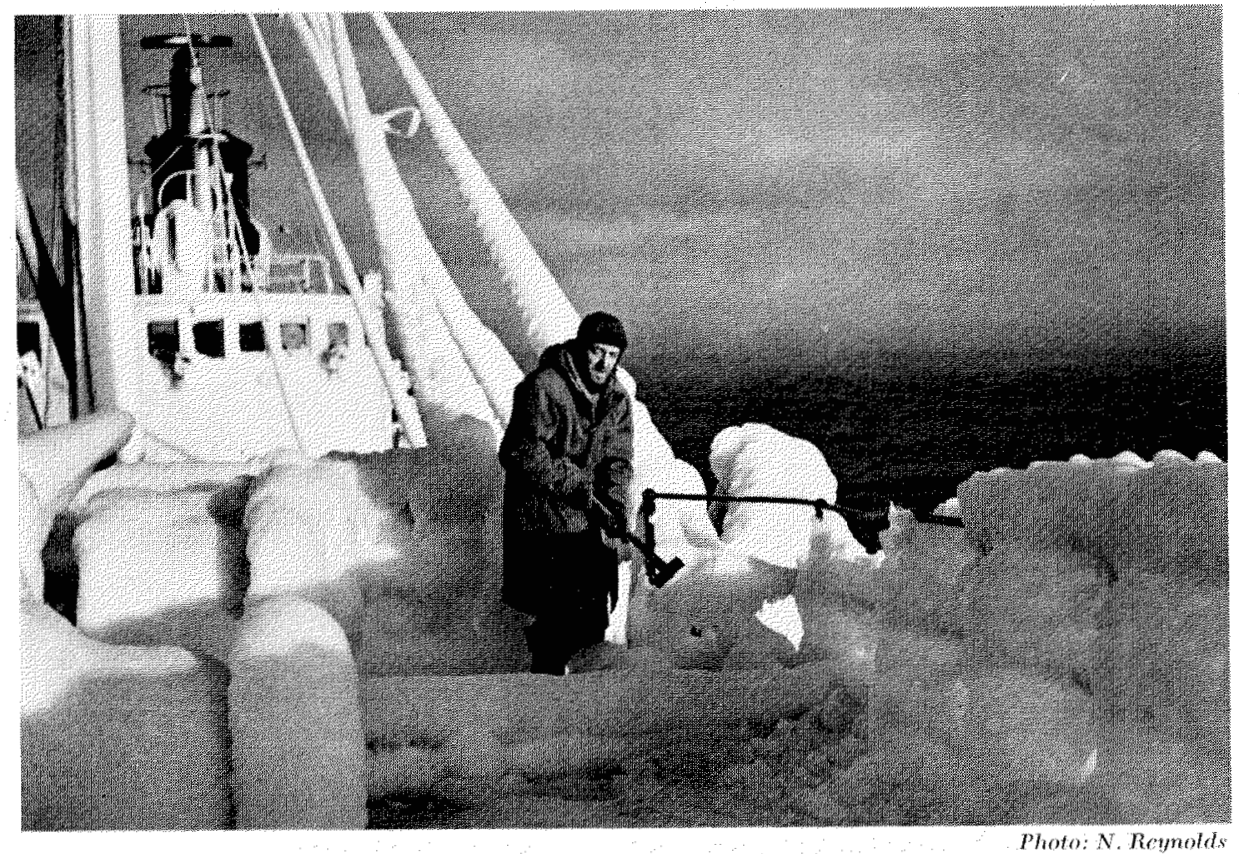

Fig. 4. Removing ice after the storm.

achieved. In the abominable month of March, most trawlers work in the more southern parts of the Barents Sea, and only hang near the ice of the Bear Island Shelf if fishing elsewhere is desperately bad. But research required that there should be no seasonal gap in information, and all months have found the ship fishing near Bear Island (Bjørnøya) and to the northeastward towards Hope Island (Hopen). There have been two deckhands injured. One had an elbow crushed when it was caught where, in normal latitudes and weather, a man would not have been foolish enough to put his elbow, and even one man injured is one too many, and is an indication that in this department too, the Ernest Holt has no margin to spare (Fig. 2).

Deck engines form the Achilles heel for the Chief Engineer, Mr. J. H. Van Ham and the 2nd Engineer, Mr. A. Baggott. After two fully qualified engineers were engaged, in place of only one, there has been no further trouble; but before that time there was a sad history of electric and steam winches in trouble when nobody expected it, spray seeping into an electric winch, or sudden frost cracking the cylinders of a steam one. In extreme cold the oil in bearings sometimes goes solid, and it was a heartening sight to see Skipper Monger light a bonfire under the main winch, which freed it after normal engineer's methods had failed. Rather surprisingly, despite the care necessary to prevent freezing, our preference is for steam winches rather than electric. The human factor is easier with steam than with electricity.

About seven voyages are made in the year, with an average duration of twenty-nine days. Naturalists-in-charge are drawn from an Arctic Team consisting of the following: M. Graham, G. C. Trout, A. J. Lee, R. J. H. 
Beverton, J. Corlett, and R. W. Blacker. The four members of the scientific staff on board do their best to work up both their biological and hydrographical observations in a preliminary fashion by the time each voyage is ended. Then the plan for the next voyage can be made to fit on to what has been found already. Continuity is maintained by a somewhat strict hand-over to the next naturalist-in-charge when the ship returns to Grimsby. By then the old naturalist-in-charge has fair charts of his observations, and as full a report as possible of the findings of his voyage. So, hearing all this, the new naturalist-in-charge can then and there make his preliminary plan for the next voyage, and discuss it with the Master and Fishing Skipper before the ship turns over to harbour routine. If necessary, the new naturalist-in-charge stays by the ship until he is sure that all preparations for his voyage are in train.

As soon as possible after the returning staff reaches the Fisheries Laboratory, a meeting of the whole team is held, at which the program for the next voyage is discussed, after which it is drafted and issued, serving as the starting basis.

As the ship steams north again, information about fishing and ice conditions begins to come in, and by the time the area of investigation is reached, the naturalist-in-charge may have modified his plan considerably. Success has sometimes depended on still further modifications as the work develops on the grounds; for which purpose it is advantageous to have the scientific staff so strong-usually three professional men and one assistant-that the naturalistin-charge may devote himself entirely to monitoring and meditation, leaving his staff to carry out all the more strenuous work. This has not always proved possible, and it has been difficult to convince young and zealous naturalists-incharge of its value.

Once a year, a program conference of the Arctic Team sits for as many days as are necessary to produce proposals for the next year's work.

In general, the scientific attack has been by the method of hypothesis followed by critical observations, rather than by survey and statistical evidence. As time has passed, hypotheses have tended to become more comprehensive, and in 1953-4 one is under test for the Hope Island area, involving a seasonal progress in nutrient salt content, phytoplankton, zooplankton, capelin, cod, fat-content, and vitamin content, with the retreat of the ice as the governing factor, and the understanding of a particular summer fishery as the immediate economic prize. At present that fishery is unpredictable and irregular, needing scientific elucidation. It was bad luck that in 1953 , as it happens, therc was not a sign of it. Understanding of that fishery might well lead very much further, with applications to all "subarctic" cod fisheries (Dunbar, 1951, 1953), popularly termed arctic.

Other areas investigated, but more superficially as yet, are near south Greenland, Jan Mayen Island, west and north of Spitsbergen, and Goose Bank near Nova Zembla (Novaya Zemlya).

In the meantime, definite advice has been given to fishermen for the months of May/June, October, November, and December, when they could use reversing thermometers with advantage. The main fishery investigated has been that on the Bear Island Shelf, where immature cod can be trawled 
Fig. 5. General current system of the western Barents Sea and the two standard hydrographical sections.

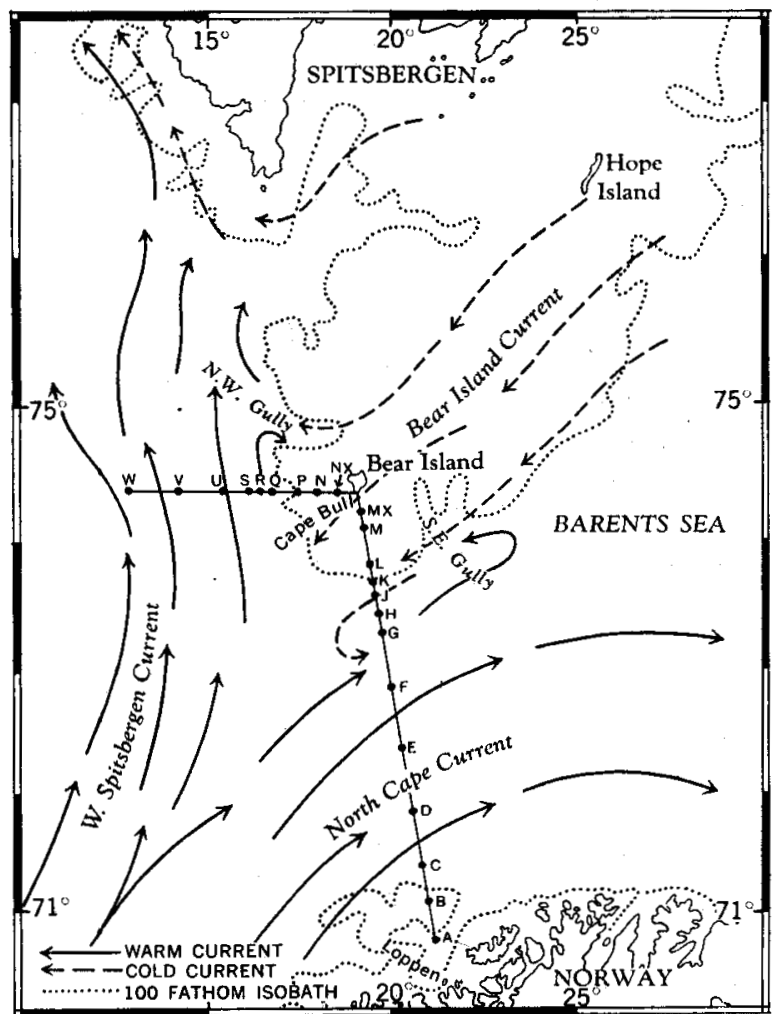

sometimes in prodigious numbers. The stock has been found to be localized in the boundary region of the West Spitsbergen Current, of Atlantic water, and the Bear Island Current, of arctic water (Fig. 5). The latter has a temperature of less than $2^{\circ} \mathrm{C}$; it is a mixture of meltwater, mainly of polar origin, with a temperature less than $0^{\circ} \mathrm{C}$, and of Atlantic water, originally of temperature of more than $4^{\circ} \mathrm{C}$, some of which has travelled round Spitsbergen and returned to the Barents Sea through the channel between Spitsbergen and Franz Joseph Land (Zemlya Frantsa-Iosifa). Not only is the cod fishery located in the general boundary region, but in certain months and localities, success in finding paying concentrations, yielding a ton and a half per hour's trawling, depends on the presence of local pockets or inversions-hydrographic structure caused by the impact of the two kinds of water. This was the main finding from the first four years' work.

Arctic workers in general may be more interested in the oceanographical observations, which are intended to form a contribution to the problem of warming and cooling of the Arctic, as it affects fisheries.

Two hydrographical sections were set up (Fig. 5): the "South Bear Island Section" from Loppen (Lopphavet) in northern Norway to Cape Bull (Kapp Bull) in Bear Island, to monitor the North Cape Current and other movements in this entry to the Barents Sea; and the "West Bear Island Section", running from Bear Island out into the deep water to the westwards, so keeping 

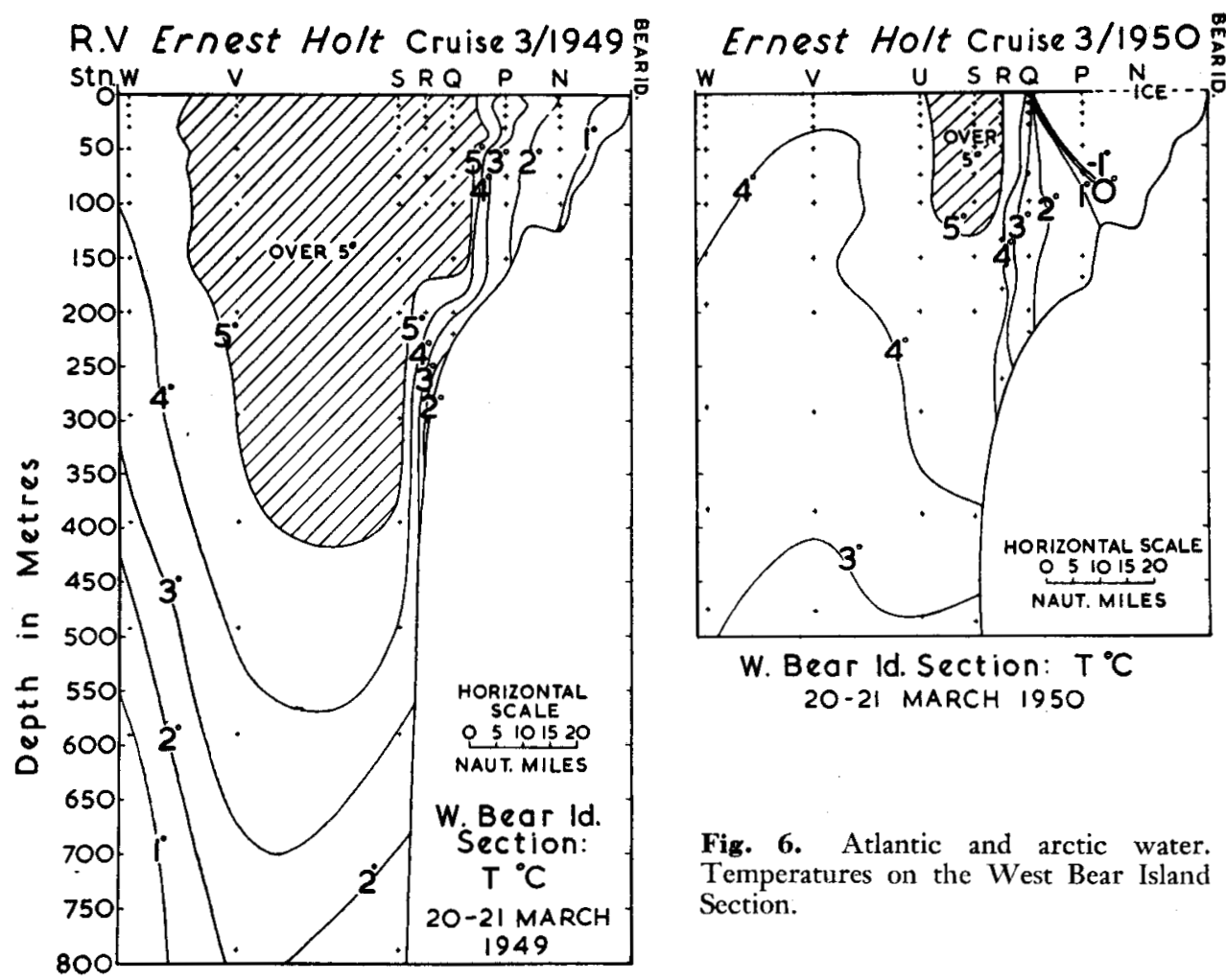

W. Bear Id. Section: $T^{\circ} \mathrm{C}$ 20-21 MARCH 1950

Fig. 6. Atlantic and arctic water. Temperatures on the West Bear Island Section.

a watch on water transport in the West Spitsbergen Current. Observations are made at the standard depths internationally agreed, and most of the stations are between 5 and 25 miles apart (Fig. 6). The original aim was to make both these sections four times per year, but it was found that the southern section was not so profitable as the western, and it has been done less frequently. In addition, surface and bottom temperatures have been taken wherever the ship found herself in all her work; and a surface thermograph has been run during most cruises. There have also been numerous bathythermograph lowerings.

The bearing of these observations on long-term warming and cooling will not be clear until several more years have passed. In the meantime, however, various oceanographical phenomena have begun to be revealed, at least in part. Sharp discontinuities in density of the water are found at certain seasons of the year, both horizontal and vertical. These are sometimes multiple in depth, and are shown by both bathythermograph and echo-sounder. The strength of the Atlantic component on the Bear Island shelf is subject to wide variation, and its interplay with the arctic component, itself varying with winter ice conditions, appears to produce one or another type of condition on the shelf, these in turn giving different types of fishing in one year as compared with another (Lee, 1952).

The nutrient salts and dissolved oxygen content of the water are proving interesting, both to hydrographers and to biologists; and the faculties meet aiso 
in the study of benthic animals, which may provide information either the frequency of extreme hydrographic conditions in different areas, or on the average conditions.

Incidental activities of the Ernest Holt have included: measuring current by plotting movement of icebergs; making a hydrographical station in latitude $80^{\circ} 38 \mathrm{~N}$.; correcting the tidal information for Bear Island; adding soundings to the charts; leading fishermen to many thousands of pounds' worth of fish; fishing once among many Russian trawlers some 150 miles east of any British ones; and the rescue and salvage of a Norwegian sealer.

It would be an omission of the relevant if $I$ failed to mention that all this is very enjoyable. That-and indeed all else-has been made possible by the ship's outstanding sea qualities. Wind of Force 12 has not harmed her, and she takes the water easily, fore or aft or on the beam. To achieve this we took, in the first instance, deckhands' advice on which existing arctic trawler was kindest to them, and then ordered one to be built with the same hull. The builders gave her more beam, and certain other modifications-all helpful it seems. She must be one of the best sea-ships afloat: that, at least, is the opinion of those who sail in her.

\section{References}

Dunbar, M. J. 1951. 'Eastern Arctic waters.' Fish. Res. Bd. Can. Bull., No. 88, 131 pp. 1953. "Arctic and subarctic marine ecology: immediate problems." Arctic, Vol. 6, pp. 75-90.

Graham, M. et al. 1954. "Research from the Ernest Holt". Fish. Invest. Ser. II. Vol. 18, No. 3.

Lee, A. J. 1952. "The influence of hydrography on the Bear Island cod fishery." Cons. Perm. Int. pour L'explor. de la Mer, Rapp. et Proc.-Verb. Vol. 131, pp. 74-102. 